\title{
Thailand and Thaksin Shinawatra: From Election Triumph to Political Decline
}

\author{
by Michael H. Nelson
}

Before the latest general election on 6 February 2005, [i] critical political observers had perceived Thailand's incumbent prime minister, Thaksin Shinawatra, as a threat to the country's fledgling democracy. [ii] It seemed that (for reasons of centralizing personal power) he did not accept the democratic rules of the game, but rather tried to narrow down the public political space, infiltrate the constitutional checks-and-balances system, and control the public access to information regarding the government's performance. This was accompanied by the implementation of a multitude of 'populist' policies that accrued tangible benefits to the great majority of voters. They repaid Thaksin's performance at the helm of government with an overwhelming election triumph. Even the voters in Bangkok, who were considered politically sophisticated and thus perhaps inclined to counter any authoritarian tendencies, convincingly backed Thaksin. Only the South withheld support, largely because of the government's mishandling of the Muslim insurgency, such as the incidents at Krue Se mosque and the Tak Bai police station, which cost dozens of lives.

\section{Corruption and cronyism}

With a majority of 375 to 125 seats in the House of Representatives, one could thus have expected the continued smooth running of the country by following Thai Rak Thai's election slogan 'Four years of repairs - four years of construction.' It is all the more surprising that, at the end of 2005, Thaksin's rule seems to rest on shaky grounds. The problems started soon after the election, in mid-April, when newspapers disclosed what was perceived as big-time corruption regarding 26 CTX luggage scanner machines bought for the new Suvarnabhumi airport. Two months later, the opposition took up this issue in a no-confidence debate against Transport Minister Suriya Jungrungreangkit. He barely survived the onslaught and subsequently lost his 
portfolio in Thaksin's tenth cabinet reshuffle on 2 August. Still, being TRT's secretary general and the leader of one of the party's most influential factions, he was merely 'demoted' to the position of minister of industry, plus the concurrent position as one of the deputy prime ministers.

The CTX scandal and other irregularities have never been transparently explained to the public. What has been offered in terms of explanations defended the government's actions rather than impartially clearing matters up. It did not help its cause that the government was seen as having colluded with allied senators, the house speaker, and constitution court judges to push Auditor General Jaruvan Maitaka out of her position just when she was persistently investigating doubtful dealings at the new airport. And the Senate appointing a new National Counter Corruption Commission stacked with members close to this government followed this questionable maneuver. As a result, Thaksin's and the government's credibility has suffered substantially. Justified or not, whatever big projects the government undertakes, many professional observers would automatically assume that 'conflicts of interest' will lead to benefits for cabinet members and their wide circles of family members and friends at the national, provincial, and local levels. The Bangkok Post (23 December 2005) reflected a widespread impression when it stated that 'cronyism and corruption has been allowed to flourish under this government.' In fact, these problems afflict most sectors of Thai society. Thaksin's promise that he would 'scrutinise his Cabinet and clear out members accused of being involved in corruption' sounds as hollow as his statement that 'corruption would be dealt with in a straightforward manner and [that] he would spare no one' (The Nation, 2 January 2006). On the issue of government corruption, the observing public and Thaksin seem to have detrimentally opposed perceptions.

\section{Newspapers under threat: Paiboon Damrongchaitham}

The dust of the cabinet reshuffle—organized, as usual, with the help of Thaksin's wife, Pojamarn (Thai papers call her nai ying, the woman boss, while her husband figures as nai yai, the big boss), who is also the single most important financier of Thai Rak Thai party as well as the owner of the party's headquarters-had barely settled, when the public was alarmed by two events concerning the mass media. On 11 September, it became known that entertainment tycoon Paiboon Damrongchaitham was about to stage-very un-Thai-hostile takeovers, financed by a Ioan from Siam Commercial Bank, of the leading Thai-language newspaper Matichon, and the English-language Bangkok Post. Paiboon's babbling about supposed content synergies between his singers and movie stars and two serious political newspapers convinced hardly anybody of his pure motives. He also admitted that he had no idea of how the newspaper business operated.

Observers pointed to the fact that Paiboon has long been a close friend of Thaksinheaving lend his hand and starlets for the PM's publicity stunts, or having joined him and 
Thaksin's daughter in the karaoke room of TRT's headquarters. They thus suspected that Thaksin was using Paiboon for gaining control over two influential newspapers that had often been critical of him and his government. Paiboon's attempt was contextualized with Thaksin's takeover and political emasculation of Thailand's only independent TV station before the 2001 election, the purging of critical political content from state TV and radio, and the intimidation of the Thai-language press, including the buying of shares of the company that owns The Nation, Krungthep Thurakit, and Khom Chat Luek, papers that have been very critical of Thaksin, by the family of TRT's secretary general, Suriya Jungrungreangkit. The public outcry greeting Paiboon's attempt was so loud that, after a few days, he retreated. In an official front-page 'Post statement,' the Bangkok Post (17 September 2005) wrote, 'we pledge to defend to the utmost the principle of freedom of expression, a crucial lynchpin in a democratic society, no matter what pressures are brought to bear.' And The Nation (20 September 2005) cautioned, 'Paiboon's retreat is no cause for celebration. The entertainment baron, or anyone else willing to serve the powers-that-be, may strike again at any time.'

After Thaksin had returned from his New-Year vacation in Singapore, he put his conception of a free press in a democratic polity under the spotlight. On the occasion of a workshop for provincial 'CEO' governors and other high-ranking civil servants, Thaksin told his audience that he was elated while reading newspapers in Singapore, such as the International Herald Tribune, The Wall Street Journal, and the Straights Times. They carried hardly any news about politics but rather emphasized innovations and the development potential of countries. This, Thaksin bemoaned, was much different from the press in Thailand (Krungthep Thurakit, 7 January 2006:2). Shortly before he made this statement, he had discontinued his weekly press conferences at Government House, introduced only a few months earlier, reasoning 'they are of no use' (ibid.). Obviously, Thaksin's professed desire for 'quiet politics' (kanmueng ning) is as strong as it was at the beginning of his first term. From his perspective, it seems, political decision- and deal-making should be confined to a small in-group of politicians and technocrats shielded from the public's eye. The people are supposed to trust the word of their 'leader,' that everything is being done by having their needs and the welfare of the country at heart. It seems that Thaksin still prefers the Singaporean and Malaysian models of political order to what he has to grapple with in his own country.

\section{The Lumpini Park phenomenon: Sondhi Limthongkul}

A few days after Paiboon's bombshell announcement, the government-owned Channel 9 TV station decided immediately to take the weekly political talk show Muang Thai Rai Sapda (Thailand Weekly) off the air. It had been broadcast live since July 2003. This decision was widely interpreted as the government's attempt to silence one of its most vocal critics, the owner of Manager newspaper, Sondhi Limthongkul. At the same time, Channel 9 kept a similar talk show 
in which two veteran right-wing politicians-cum-commentators, Samak Sundaravej and Dusit Siriwan, are given a free hand to attack the government's critics.

If it was the government's intention to silence Sondhi, its move backfired badly. On 23 September, the first 'mobile' talk show was performed at Thammasat University's small auditorium, drawing many more listeners than the 1,000 seats available. As the venue became too small, Sondhi moved to Lumpini Park. When I attended one of the shows on 25 November, around 40,000 people were in the audience; the week afterwards saw 80,000, and then dwindled until the last show before new year on 23 December to 10,000 to 40,000 people, depending on the source of information.

Usually, Sondhi would accuse the Thaksin government of corruption and other forms of wrongdoings. For example, he disclosed that Thaksin's younger sister had used an air force transport plane to bring friends to her birthday and housewarming party to Chiang Mai-similar behavior, in fact, is widespread throughout Thai political, bureaucratic, academic, military, and police circles. He also criticized that Thaksin had improperly intervened with the work of the Supreme Patriarch. Sondhi and his followers wore yellow t-shirts with 'We will fight for the King' printed on them, while a banner above Manager newspaper's masthead demanded 'Return the power to the King' (thawai khuen phraratchaamnat). The implication was that Thaksin had been disloyal to the King and misused the power bestowed upon him by the King based on the people's election mandate. Therefore, the King's power should be returned to him so that the people could decide anew. Indeed, it were Sondhi's references to the monarchy that were used as pretext to cancel his program.

Thaksin responded by throwing a number of libel suits against his accuser. However, he was not content with aiming for Sondhi's and his co-moderator's criminal indictment. Thaksin also brought civil cases against them at the tune of two billion baht in damages. Obviously, this is an obscene amount. How could the 'honor' of an elected public figure such as the prime minister be worth this much? This procedure did not primarily demonstrate Thaksin's incredibly inflated sense of self-importance. Rather, it reflected an emotionally-driven sense of revenge aimed at destroying an adversary - mind you, not an adversary in Thaksin's private life, but a critic in the public sphere of a democratic state. On the publicly voiced advice of the King, Thaksin later withdrew these suits. Indeed, the conflict between Sondhi and Thaksin was often cast in personal terms, as if two 'rivals' fought out their private antagonisms. Both are Chinese-Thai businessmen with high degrees of arrogance, acting in emotional, erratic, egotistical, and megalomaniac ways. Interestingly, until quite recently, Sondhi had used his newspaper to sing the praises of Thaksin's greatness. Thus, doubts arose as to what had motivated his U-turn and the vicious attacks. These doubts contributed to keeping most well-known political activists away from participating in the Lumpini Park phenomenon. A famous social critic, Sulak Sivaraksa, asked whether he would 
join Sondhi, quipped 'That's bastard against bastard, evil versus evil. Sondhi would sell himself at any time if the price is right' (The Nation, 20 December 2005).

Observers were not only thrilled by the great number of people who turned up on Friday evenings at Lumpini Park. Rather, they got excited because of the purpose of these mass gatherings. Sondhi had been ambivalent about his goals; but on 25 November, he called on his listeners one week later to bring together 200,000 people to show Thaksin that he had lost all legitimacy to remain prime minister. Obviously, nothing less than toppling the government was at stake-a government that had received overwhelming electoral legitimacy just a few months ago. Comparisons were drawn to the 1973 and the 1992 uprisings; coup rumors popped up; soldiers warned Sondhi that their patience had its limits, others went to see him with a letter of protest; a small bomb was lobbed into Manager's compound; people intruded into the office and smeared walls with animal excrements.

The political atmosphere became quite tense. Since then, talk of getting rid of Thaksin has become fashionable in some quarters. Sulak would not join Sondhi, but his aim was the same: 'We must organize ourselves to overthrow Thaksin,' Sulak told some 400 people at a symposium to mark his 72nd birthday' (The Nation, 20 December 2005). From this point of view, Thaksin does not appear to be a democratically elected prime minister, he seems to resemble past military strongmen, such as Thanom Kittikachorn or Suchinda Kraprayoon, instead. Another old element of Thai political culture has also been recycled, namely guessing when this government will be gone, or when Thaksin would dissolve parliament. A more recent elementthat any House of Representatives normally should serve out its four-year term-does not seem to have much currency. Again, it is sectors of the Bangkok elite that ascribe themselves the right to overrule the electoral legitimacy created by the great majority of rural (and 2001 and 2005 even the Bangkok) voters. The underlying justification is aptly put by one of Thaksin's critics, Roj Ngarm-maen, a famous journalist who writes in Thai Post under his penname Plaew Si-ngern: 'The lower classes are underprivileged and passive. They are not allowed to think. If you want to say that the rural people vote for a government while the middle class ousts it, then that may be right. Society must be propelled by the middle classes. The lower classes are just followers. Look at any dictator, be it Thanom [Kittikachorn], Prapas [Charusathien] or Suchinda [Kraprayoon], and you'll find that the rural folk put up no opposition' (The Nation, 24 December 2005). One cannot view this statement merely as an expression of capital-city arrogance. Unfortunately, it has a structural basis in the doubtful democratic quality of politics and voting in rural constituencies. [iii] And TRT reacted by paying more attention to Bangkok's voters in an attempt to ease pressure stemming from its declining popularity in the Capital. 


\section{Thaksin weaker - Thai Rak Thai's factions stronger}

As a result of Thaksin's 'decline' (kha long), some of Thai Rak Thai's about 14 or 16 factions (Krungthep Thurakit, 9 February 2005:16; Matichon, 10 February 2005:2) became more selfconfident. Not only did they indicate that they wanted more ministerial positions and a change of the constitution's 90-day rule that prevents MPs from switching parties shortly before elections. Rumors were also spread that some factions had toyed with the idea of breaking away from TRT to establish a new political party. However, as Krungthep Thurakit (7 January 2006:8) cautioned: 'Who will agree to throw away his power and benefits and chose the very beginning of a difficult new path elsewhere, if it was not for fierce conflicts [carried through] to the end?' In any case, the deteriorating situation within TRT prompted Thaksin to hold an 'urgent' lunch meeting on 8 December with leaders of important factions in order to calm things down. Somsak Thepsuthin, one of the leaders of the Wang Nam Yom faction, whose supremo is TRT's secretary general Suriya Jungrungreangkit, on 24 December declared, that his faction was 'not out to make trouble' (The Nation, 25 December 2005). Thaksin tried to pour more oil on troubled water by announcing that he would 'not stab anybody in the back,' meaning that he would 'allow more than 90 days to lapse before the polls' (The Nation, 31 December 2005). Observers shall also like to watch the actions of a cabinet member who is very close to Thaksin: Transport Minister Pongsak Raktapongpisak. He has been quietly building up his own faction within TRT, perhaps on behalf of Thaksin who might want to create some counter-weight to other groups, especially that of Suriya Jungrungreangkit (The Nation, 23 December 2005).

Thaksin himself is not afraid of factional conflicts: 'I am confident that I can handle the various factions in my Thai Rak Thai Party even though many journalists are trying to blow factional views out of proportion' (The Nation, 2 January 2006). Nevertheless, sustained speculation has it that TRT's internal strife will lead to a cabinet reshuffle around February 2006. An important problem in this context is whether the prime minister's wife, Pojamarn, who does not occupy any formal elective or administrative position, will be willing to sacrifice 'her' ministers in order to pacify the party's factions by giving their leaders more positions in the cabinet (Thai Rath, 1 January 2006:3). The same paper states: 'This cabinet reshuffle will be done more for improving the government leader's political stability than for the [cabinet's] work efficiency.' As for Pojamarn's role, her 'influence on the administration of the country' has steadily increased, and it is said to encompass the appointment and transfer of soldiers, policemen, the interior ministry's section chief in the provincial administrations (palad changwat), chief district officers, provincial governors, and others (Matichon, 1 January 2006:3). This influence, as opposed to TRT's cliques (wang, kuan, klum, or mung), is sometimes referred to as 'chansongla,' Shinawatra's residence on Charansanitwongse road in Thonburi. 
Thaksin's predicament has also led non-TRT groups to develop new political hope and ponder their options. Mahachon party's Sanan Kachornprasart, outgoing senator Manoonkrit Rupkachorn, and disposed Mahachon leader Anek Laothamatas, and their respective groups, all have been busy at expanding their networks and figuring out what kind of coalition might lead to the establishment of a viable political party able to compete with TRT and the Democrats in the next election scheduled for March 2009. Even Chalerm Yoobamrung has emerged from political hibernation and announced the founding of a 'New Alternative Party' for January 2006. The civilsociety sector, including politicians of the oppositional Democrat party, has seen efforts at starting a 'second-round political reform' aimed at filling the constitutional 'loopholes' that the initiatorsamongst them are old faces such as Amorn Chantarasomboon, Kanin Boonsuwan, Pithya Wongkul and Suriyasai Katasila of the Campaign for Popular Democracy, or the inevitable Prawase Wasi- think have enabled Thaksin to expand his powers far beyond of what the Constitution permits and what is healthy for Thai democracy. On 18 December, a 'People's Assembly' on constitutional reform, privatization, and corruption was held at Chulalongkorn University. One wonders what brings these activists to believe that yet another round of constitutional engineering - a manifestation of the Thai habit of introducing structural changes in the hope people's behavior will improve-might succeed at what the first round failed. As an observer remarked, the constitution is all right-it is the people who try to circumvent it who are at fault.

\section{Outlook: six months of suspense}

Observers of Thai politics see the next six months as crucial for Thaksin's political standing. A number of events will give the public opportunities for further developing their views of Thaksin and his government. This might start in February with the Supreme Administrative Court deciding the fate of the government's plan to privatize the Electricity Generating Authority of Thailand (EGAT). Non-governmental organizations had temporarily blocked this by acquiring a court order. To some, the Administrative Court became some sort of hero, or a symbol as the last bastion of the constitution's checks-and-balances system not yet captured by Thaksin's cohorts. The Nation even declared the court's president 'Person of the Year.' Opponents of EGAT's privatization had joined Sondhi at Lumpini Park. A report by Merryll Lynch Phatra Securities anticipates that if the court's decision enables Sondhi to strengthen the forces opposing Thaksin, then the 'political temperature might increase even more' (reported in Matichon, 5 January 2006:2). A further contributing factor might be a cabinet reshuffle, speculated to take place also in February, which probably will turn out to be disappointing.

On 19 April 2006, the second election to the Senate will take place. The majority of the present senators has come to be seen as supporting Thaksin. Journalists, in their customary giving of alias-names to Thai political institutions and politicians to mark the end of the year, 
denounced this Senate as 'assembly of slaves.' This contrasts sharply with the Senate's constitutional role as an apolitical and neutral chamber the members of which must not belong to political parties, and not conduct any election campaigns. Strong signs indicate that the next set of senators will be even less 'neutral.' Many prospective candidates are relatives and political friends of TRT MPs and sitting senators. In newspapers, the next Senate is anticipated to be an 'assembly of relatives.' Thai Rath (1 January 2006:3) stated: 'For sure, those having political power will certainly not waste this golden opportunity to absolutely dominate the Senate.' And Matichon (1 January 2006:3) added: 'If it turns out that many people supported by this government are able to get into the Senate, then a current of democratic dictatorship will immediately begin.' The question then is how the public in Bangkok will react if this prospect becomes reality.

Finally, since the parliamentary session starting in March will be a general session, the opposition is allowed to initiate a no-confidence debate against ministers. And since it gained two more MPs in by-elections, the opposition has reached the number of 125 MPs necessary to not only criticize the incompetence of ministers but to attack them on the ground of corruption. Obviously, the power of the no-confidence debate-expected for May-will depend on whether the opposition can manage to acquire convincing data on the targets' misbehavior, and whether it can imply any responsibility of the prime minister. Thaksin cannot directly be targeted because the opposition does not have the required 200 MPs for censuring him. A convincing attack might lead to yet another cabinet reshuffle as well as to a further decline in Thaksin's and his government's public support. In turn, this might strengthen a trend Thai Rath (1 January 2006:3) identified as an increasing role of the people's sector in politics-although the paper carefully avoided mentioning Sondhi or Lumpini Park, or speculating about this phenomenon's prospects in the first few months of the new year. People, the paper said, have become more aware of Thaksin's actions: 'Simply speaking, the paint once applied has started to peel off.' Moreover, the attempts by various quarters at getting a new round of constitutional amendments under way might gain steam.

The Nation (5 January 2006), a paper that for some time has been trying to write Thaksin out of office, commented: 'In May, it will be seen clearly whether Thaksin still has the legitimacy to rule. He will likely be badly bruised by the political attacks. Will he survive?' In the same edition, Suthichai Yoon headlined his column 'Post-Thaksin scenarios no longer just dreams.' Yet, all the above events might well not lead to a situation where the alternative is whether Thaksin will pass the test or fail the test, as it was expected by Matichon (1 January 2006:3). After all, politics often is not about black and white, but rather about a grey-zone of political survival by muddling through, and not losing one's nerve when facing adversity, especially if one commands a solid parliamentary majority. It would help his cause, however, if Thaksin could develop a greater 
degree of political-communicate maturity as well as some tolerance towards criticism. A bunker mentality that sees one's own group attacked by a surrounding force of enemies out to get them can only contribute to Thaksin's political demise. It is hoped that no confrontation will occur between the rural population that legitimizes Thaksin, and sections of Bangkok's public that try to force him out of office. Finally, some thought ought to be given to the question of what and who might come after Thaksin.

Michael $\mathbf{H}$. Nelson is a visiting scholar at the Faculty of Political Science, Chulalongkorn University, Bangkok, Thailand.

[i] For details see Michael H. Nelson. 2005. "Thailand's 2005 General Election: Thaksin's Triumph - Political Reform's Defeat?" Paper presented at the Second International MalaysiaThailand Conference on Southeast Asian Studies (UKM-Mahidol 2, 2005 Conference), Universiti Kebangsaan Malaysia, 29 November-1 December 2005. (obtainable at mhnelson_bkk@yahoo.de)

[ii] Two book-length analyses of Thaksin's rule are Pasuk Phongpaichit and Chris Baker. 2004. Thaksin: The Business of Politics in Thailand. Chiang Mai: Silkworm; and Duncan McCargo and Ukrist Pathamanand. 2005. The Thaksinization of Thailand. Copenhagen: NIAS Press.

[iii] See my paper "Analyzing Provincial Political Structures in Thailand: phuak, trakun, and hua khanaen." Hong Kong: Southeast Asia Research Centre, City University of Hong Kong, 2005. (SEARC Working Paper Series, No. 78, www.cityu.edu.hk/searc) 